\title{
ASSESSMENT OF THE SOCIO-ECONOMIC IMPORTANCE OF THE CULTURE SECTOR IN THE EU COUNTRIES
}

\author{
[Hodnocení socio-ekonomického významu sektoru kultury v zemích EU] \\ Eva Ardielli ${ }^{1}$ \\ ${ }^{1} V S ̌ B-$ Technical University of Ostrava, Faculty of Economics, Sokolská 33, 70200 Ostrava \\ Email:eva.ardielli@vsb.cz
}

\begin{abstract}
The culture sector is from the European or national perspective often designated as a dynamic segment of the economy, which is also characterized by high rates of GDP growth. This fact reinforces the importance of the sector within the European Union, as GDP growth belongs among the primary goals of the Community, in accordance with European legislation and key EU documents. However, from the socio-economic perspective the benefits of culture sector are economically difficult to quantify. The paper is focused on the problems the culture sector assessment from the point of view of socioeconomic importance in the international context of the European Union. The research is based on the usage of MCDM methods (TOPSIS and WSA). The results are focused on the comparison of the socioeconomic importance of the culture sector in EU member countries. For the assessment are chosen 7 socio-economic culture indicators describing the importance of culture sector in the country. The results of two selected MCDM methods are verified on the basis of correlation analysis.
\end{abstract}

Keywords: assessment, culture sector, European Union, MCDM methods, socio-economic importance.

JEL classification: H11, H41, Z18

Doručeno redakci: 29.4.2017; Recenzováno: 6.5.2017; 12.5.2017; Schváleno k publikování: 20.9.2017

\section{Introduction}

Culture and arts represent the essential part of human existence, especially in terms of historical, symbolic, aesthetic and spiritual values. Despite its undisputed social importance this sector has also been becoming more important from economic perspective in the last years (Colombo 2006, van der Pol 2008 or European Commission 2006, Zedková 2016). The culture sector of European Union can be described as a growing segment of the economy with high rates of GDP growth, gross value added and dynamic development of employment. Potentially it has the characteristics of a leading sector that can generate growth of the overall economy as stated by UNESCO (2009). This fact reinforces the importance of the sector within the European Union, as GDP growth and the high level of employment belong among the primary goals of the Community, in accordance with European legislation and key EU documents (European Commission 2006).

However, in the past the culture was largely ignored in the term of socio-economic importance and degraded only on the unproductive sector. For example Craik (2005) states the cultural policy as not justifiable policy of government in terms of essentiality and unavoidability with other public good policy domains as prisons, defence or infrastructure. Moreover the area of culture is just one small component of the public agenda that governments are obliged to support. Despite all the importance that is nowadays seen in culture sector, economic benefits in this area are difficult to quantify. Therefore the evaluation and comparison of the socioeconomic importance of the cultural sector with other industry fields belong to the current trends (UNESCO 2009 or Throsby 2004). This is also the reason of the focusing of this article on the problems of evaluation possibilities of the culture sector from the perspective of socioeconomic importance. 
The objective of this article is to evaluate the socio-economic importance of culture sector in the EU member countries by usage of multi-criteria decision-making methods (MCDM). The scope of evaluation includes the non-industrial culture sector (fine arts, scenic arts and cultural heritage) and industrial culture sector (film, music, book publishing and printing). The evaluation is based on the application of TOPSIS and WSA method by processing of economic data on culture monitored by Eurostat. In the article interesting results focused on comparison of culture sector on the international level of the European Union are offered. The results of different MCDM methods are verified based on the correlation analyses.

\section{Importance of Culture at the EU Level}

Culture is one of Europe's greatest strengths: it is a source of values and identity and it gives the continent a sense of belonging. It also contributes to people's well-being, to social cohesion and inclusion. The cultural and creative sectors are a driver of economic growth, job creation and external trade (Eurostat 2016, European Commission 2006). Cultural and creative industries are estimated to be responsible for over $3 \%$ of the EU's gross domestic product and jobs (Europa 2017).

At EU level, culture was legislatively enshrined in the Maastricht Treaty for the first time in 1992. Its importance is also mainly declared in the Lisbon Strategy, document Europa 2020 and other strategic documents. In accordance with Article 167 of the Treaty of the Functioning of the EU, the EU shall contribute to the flowering of the cultures of the member states, while respecting their national and regional diversity and at the same time bringing the common heritage to the fore (Eurostat 2016). Activities in this area are framed by the European Agenda for Culture, which aims to reinforce the role and position of culture in an increasingly globalized world (Europa 2017). However, at the EU-level the harmonization of the laws and regulations of the EU member states does not exist in the field of culture. The responsibility for this field is uniquely given to individual member states. EU in the field of culture only supports and complements the member states (Klamer, Petrova and Mignosa 2006).

EU contributes to promoting cultural activities in Europe, in particular through its programs and policies. The EU main objective is to ensure policy development and dialogue in the field of culture and to support the cultural and creative industries and professionals (by means of a variety of initiatives). The EU supports the development of the culture sector by significant financial resources through European cohesion funds. Very important is the Creative Europe programme, as well as a number of policy actions set out in the Work Plan for Culture for 2015 - 2018. European Culture Programs - Culture was introduced in the period 2007 - 2013 and 2000 - 2006. Creative Europe programme was launched at the beginning of 2014. Set to last until 2020, it provides a variety of opportunities for culture sector organizations and professionals (Europa 2017). The Work Plan for Culture, adopted by EU culture ministers in December 2014, sets out the main priorities for European cooperation in cultural policymaking: inclusive and accessible culture, the promotion of cultural heritage, support to the flowering of the cultural and creative sectors, and promotion of cultural diversity and of culture in EU external relations (Eurostat 2016). Positive impact on culture sector have also other programs that promote culture through specific cultural projects, e.g. program Europe for Citizens (2007 - 2013), and programs to promote multilingualism and exchanges of young people. In the field of cinema since 1991 the MEDIA program has been active; it aims to promote European audiovisual works; now it is MEDIA Mundus. Financial support is also offered by the Financial Mechanisms EEA/Norway. 


\section{Problem Description and Data}

Measuring of socio-economic importance in the public sector has received much attention in recent years and is nowadays considered as necessity. It is given by the fact that the public funds are limited and the governments are under increased pressure of citizens in sense of "giving value for money" (Mihaiu 2014). Measuring of socio-economic importance has been introduced above all in many public organizations in order to ensure transparency of public decisions and the use of public funds and to increase performance. But it is also the appropriate instrument for measuring of the overall performance of a country's public sector (Van de Walle 2008, ECB 2003 or World Bank 2016).

Measuring of socio-economic importance is applied increasingly in public sectors of health or education. However as stated by Chiaravalloti (2014), due to the evidence-based evaluation policies introduced by many European governments since the 1990s, the socio-economic evaluation has become also a dominant means of government control of the publicly funded culture sector. So the evaluation and comparison of the socio-economic importance of the culture sector with other industry fields belong also to the current trends (Throsby 2004). But in practice is socio-economic importance measuring in culture sector dealing with number of difficulties as identifying suitable indicators or implementation of evaluation management system, as stated by Mihaiu (2014). A large range of indicators was introduced for purpose of measuring of socio-economic importance and socio-economic benefit (Keyvan-Ekbatani and Cats 2015). The indicators are traditionally focused on financial measures (Turbide and Laurin 2009) but actually there were by many authors justified also non-financial indicators above all in case of measurements in not-for-profit organizations (Kaplan and Northon 2001, Cai and Wang 2012). The vast majority of organizations in culture sector (not-for-profit organizations performing artistic disciplines as circus, dance, music, theatre or variety) use to measure the socio-economic performance the multiple indicators (Turbide and Laurin 2009 ).

The assessing of national culture sectors from the point of view of the socio-economic importance of culture sector can be done in different ways, contexts and approaches (UNESCO 2009 and Chiaravalloti 2014). The basic approaches used to measure the socio- economic contribution of cultural sector are based on variables of macroeconomic aggregates - gross value added, turnover, employment, business activity. The aim of these indicators is to measure the dynamic of culture sector at the economic level and to provide reliable data as the basis for future decision-making in this area (UNESCO 2009). All this areas were included also into the presented research to compare the state of culture sector in EU countries.

The methods used for the evaluation of socio-economic importance in public sector are very broad. In case of performance evaluation public organizations in selected public sectors are often used Data Envelopment Analysis (DEA) (Wang et al. 2016) or Balanced Scorecard (Badia and Borin 2012, Kaplan and Northon 2001). There are used also other measuring approaches as economic-size and structural analysis, cluster analysis or cultural satellite accounts (UNESCO 2009). As stated by Shaout and Yousif (2014), for the evaluations of the selected sectors of national economies are often used MCDM methods. For example Dincer (2011) analysed the EU countries and candidate countries in terms of economic activity for the year 2008. For the purpose of the alternatives ranking were applied TOPSIS and WSA. The MCDM methods - TOPSIS, WSA, VIKOR, AHP were also used for evaluation of performance in health system (Karadayi and Karsak 2014) or evaluation of public transportation services (KeyvanEkbatani and Cats 2015). The MCDM methods were chosen also for the evaluation of socioeconomic importance in culture sector in the presented paper. 
In this article the socio-economic evaluation of culture sector importance of EU member countries was performed based on 7 culture indicators selected from the Eurostat database (Eurostat 2016) reflecting the socio-economic importance of culture sector. The evaluation in this paper is not limited only to publicly funded culture but there is evaluated the state of overall cultural industry of the countries, because this is the prerequisite for a competitive economy and contributes to economic growth and employability, as stated in Lisbon strategy. The selected indicators are describing the economic importance of national culture sector in the country, there is also reflected the expansion and dynamics of cultural sector businesses and the willingness of individuals to be active within this sector in accordance with approaches of measuring of socio-economic importance of culture by OECD (2006) and UNESCO (2009). This way are the indicators comparing the EU countries from the point of view of socioeconomic importance and give the information about the competitiveness of culture sector on international level. The summarization of monitored culture indicators and their importance and justification for measuring of socio-economic importance are summarized in Table 1.

Table 1: Culture indicators and their justification

\begin{tabular}{|c|c|}
\hline Indicator & Characteristic and justification \\
\hline GVA - Gross value added $\left(\mathrm{I}_{1}\right)$ & $\begin{array}{l}\text { At basic prices, in the sector of arts, entertainment and recreation, } \\
\text { measured in percentage of total. The value added of culture sector is } \\
\text { main economic indicator measuring the contribution of culture on the } \\
\text { production. }\end{array}$ \\
\hline $\begin{array}{l}\text { FCE - Final consumption } \\
\text { expenditure of households }\left(\mathrm{I}_{2}\right)\end{array}$ & $\begin{array}{l}\text { For recreation and culture, in } \% \text { of total services. Spending by } \\
\text { households or individuals on cultural goods and services provides an } \\
\text { economic measure that can be related to overall spending by } \\
\text { households. }\end{array}$ \\
\hline $\begin{array}{l}\text { CE - Cultural employment, } \\
\text { Percentage of total employment }\left(\mathrm{I}_{3}\right)\end{array}$ & $\begin{array}{l}\text { Statistics on cultural employment relate to the number of workers } \\
\text { (employees and self-employed) in the cultural field in percentage of } \\
\text { total employment. It is necessary to measure the employment working } \\
\text { in cultural occupations to define the overall size and structure of the } \\
\text { sector. }\end{array}$ \\
\hline $\begin{array}{l}\text { ST - Students in tertiary education } \\
\text { studying culture-related fields }\left(\mathrm{I}_{4}\right)\end{array}$ & $\begin{array}{l}\text { Provided by universities and other higher education institutions. The } \\
\text { following broad fields of education are considered to be culture-related: } \\
\text { Arts, Humanities, Journalism and information and Architecture and } \\
\text { town planning. Tertiary education plays an important role in society in } \\
\text { determining employability and the specialisation of the workforce, } \\
\text { therefore measuring of this may be appropriate }\end{array}$ \\
\hline $\begin{array}{l}\text { NCE - Number of cultural } \\
\text { enterprises }\left(I_{5}\right)\end{array}$ & $\begin{array}{l}\text { Count of the number of enterprises active during the reference period as } \\
\text { a percentage of total services in the year 2013. The expansion and } \\
\text { dynamics of culture sector is essential part of modern economy. They } \\
\text { are drivers for innovations and competitiveness. They concerns also the } \\
\text { turnover and value added of enterprises, see below. }\end{array}$ \\
\hline $\begin{array}{l}\text { CST - The cultural sectors' turnover } \\
\left(\mathrm{I}_{6}\right)\end{array}$ & $\begin{array}{l}\text { The total value of market sales of goods and services. Turnover } \\
\text { comprises the totals invoiced by the observation unit during the } \\
\text { reference period (year 2013), and this corresponds to market sales of } \\
\text { goods or services supplied to third parties; it includes all duties and } \\
\text { taxes on the goods or services invoiced by the unit with the exception of } \\
\text { the VAT invoiced by the unit to its customer and other similar } \\
\text { deductible taxes directly linked to turnover; it also includes all other } \\
\text { charges (transport, packaging, etc.) passed on to the customer. Price } \\
\text { reductions, rebates and discounts as well as the value of returned } \\
\text { packing must be deducted. }\end{array}$ \\
\hline $\begin{array}{l}\text { VA - Value added in cultural sectors } \\
\left(\mathrm{I}_{7}\right)\end{array}$ & $\begin{array}{l}\text { As } \% \text { of value added in total services in the year } 2013 . \text { Value added at } \\
\text { factor costs is the gross income from operating activities after adjusting } \\
\text { for operating subsidies and indirect taxes. It can be calculated as the } \\
\text { total sum of items to be added }(+) \text { or subtracted }(-) \text {. }\end{array}$ \\
\hline
\end{tabular}

Source: Eurostat (2016), OECD (2006), UNESCO (2009), own processing. 
The research was based on the dataset of Eurostat related to the Culture statistics. Culture statistics presents a selection of indicators on culture pertaining to the following topics: cultural employment, international trade in cultural goods, cultural enterprises, cultural participation, use of internet for cultural purposes and private cultural expenditure (Eurostat 2016). From this dataset the indicators were selected with socio-economic informative value and comparable data of the year 2014, so the observation concerns the year 2014. The indicators $I_{1}-I_{7}$ cover the area of: gross value added, household's expenditures, employment, education and the cultural enterprises activity - turnover and value added.

In the research, there was selected the final list of alternatives (EU-28 countries) and criteria (7 culture indicators) as the input for applying of two different MCDM methods - TOPSIS and WSA. Both TOPSIS and WSA methods are operations research methods that are used for multicriteria decision-making. TOPSIS method is based on the usage of the principle of minimizing the distance from the ideal option. It arranges the alternatives according to the indicator of relative distance from baseline (hypothetically worst) alternative (Chen and Hwang 1992). This method determines the overall order of alternatives in the result. WSA method is based on the principle of utility maximization. It arranges the alternatives in the order according to the total utility, which takes into account all represented criteria (Fiala 2008).

\section{Methods}

The assessment of EU countries according to the selected culture indicators was performed by application of TOPSIS and WSA methods. The both methods provide the complete ranking of the alternatives starting from the best towards the worst one. TOPSIS method is based on the selection of alternative that is the closest to the ideal solution and the furthest from baseline solution; see Shih, Shyur and Lee (2007). Application of TOPSIS method is as follows:

- Creation of normalized criteria matrix $R$ according to following formula (1):

$$
r_{i j}=\frac{\mathrm{y}_{i j}}{\sqrt{\sum_{i=1}^{m} \mathrm{y}_{i j}^{2}}}
$$

where $r_{i j}$ are elements of matrix $R ; i=1,2, \ldots m ; j=1,2, \ldots r ; y_{i j}$ are the original input data for alternative $i$ and criterion $j ; m$ is the number of alternatives.

- Calculation of weighted criterion matrix $W$ by following equation (2):

$$
w_{i j}=v_{i} \cdot r_{i j}
$$

in such a manner that each column of the matrix $R$ will be multiplied by the corresponding weight criterion $v_{i} ; w_{i j}$ is weight normalized value and $v_{i}$ is weight of criterion.

- Determination of the ideal and basal alternative relative to the matrix values $W$, see following formulas (3) and (4):

for $i=1,2, \ldots m$ and $j=1,2, \ldots r$.

$$
\begin{aligned}
& H_{j}=\max _{i} w_{i j} \\
& D_{j}=\min _{i} w_{i j}
\end{aligned}
$$

- Distance calculation of alternatives from the ideal alternative, respectively basal alternative, see formula (5) and (6):

$$
d_{i}^{+}=\sqrt{\sum_{j=1}^{r}\left(w_{i j}-H_{j}\right)^{2}}
$$


for all $i=1,2, \ldots m$; and $j=1,2, \ldots r$.

$$
d_{i}^{-}=\sqrt{\sum_{j=1}^{r}\left(w_{i j}-D_{j}\right)^{2}}
$$

- Calculation of the relative distance indicator of variants from baseline variant by formula (7):

where $i=1,2, \ldots m$;

$$
c_{i}=\frac{d_{i}^{-}}{d_{i}^{+}+d_{i}^{-}}
$$

- Arrangement of variants by non-growing values of $c_{i}$.

WSA method is based on linear utility function. The method provides complete ranking of alternatives according to their total utilities. Application of WSA consists of the following steps:

- Normalization of input data using following equation (8):

$$
r_{i j}=\frac{y_{i j}-D_{j}}{H_{j}+D_{j}}
$$

where $r_{i j}$ are the normalized values for $i$ alternative and $j$ criterion, $y_{i j}$ is original value of alternatives according to the criterion $j, D j$ are the values of the basal alternative and $H j$ are values of the ideal alternative.

- Calculation of the total utility according to the following formula (9):

$$
u\left(a_{i}\right)=\sum_{j=1}^{k} v_{j} r_{i j}
$$

where $u\left(a_{i}\right)$ is the total utility of the alternative $a_{i}, r_{i j}$ are normalized values from the previous step, $v_{j}$ is the weight of $j$-th criteria and $k$ is the number of criteria.

The results of both methods TOPSIS and WSA were verified on the basis of correlation analysis. Since we need to examine the tight dependence between the two sequence variables, we will use Spearman's correlation coefficient, which is calculated according to the formula (10):

$$
r_{s}=1-\frac{6 \sum_{i=1}^{n}\left(i_{x}-i_{y}\right)^{2}}{n \cdot\left(n^{2}-1\right)}
$$

where $i_{x}$ and $i_{y}$ are the values of of sequence variables.

Verification of the statistical significance of the given dependence is performed by means of the test:

$H_{0}: \rho_{s}=0$,

$H_{1}: \rho_{s} \neq 0$.

The test criterion for this test is the statistic $t$, which is determined by the formula (11):

$$
t=\frac{r_{s}}{\sqrt{1-r_{s}^{2}}} \sqrt{n-2}
$$


The critical field is given by inequality (12):

$$
W a=\left\{t ;|t| \geq t_{1-\frac{a}{2}}\right\}
$$

where $t_{1-\frac{a}{2}}$ is a $t$-distribution with (n-2) degrees of freedom.

\section{Results and Interpretations}

The socio-economic evaluation of culture sector importance of EU member countries was performed based on the two MCDM methods. In this part of the paper there are presented the application results of TOPSIS and WSA methods. The verification of the methods used is performed based on the correlation analyses. The evaluation of the culture sector in the EU countries in 2014 according to TOPSIS method is shown in Figure 1.

Figure 1: Assessment of culture sector in EU countries by TOPSIS method (2014)

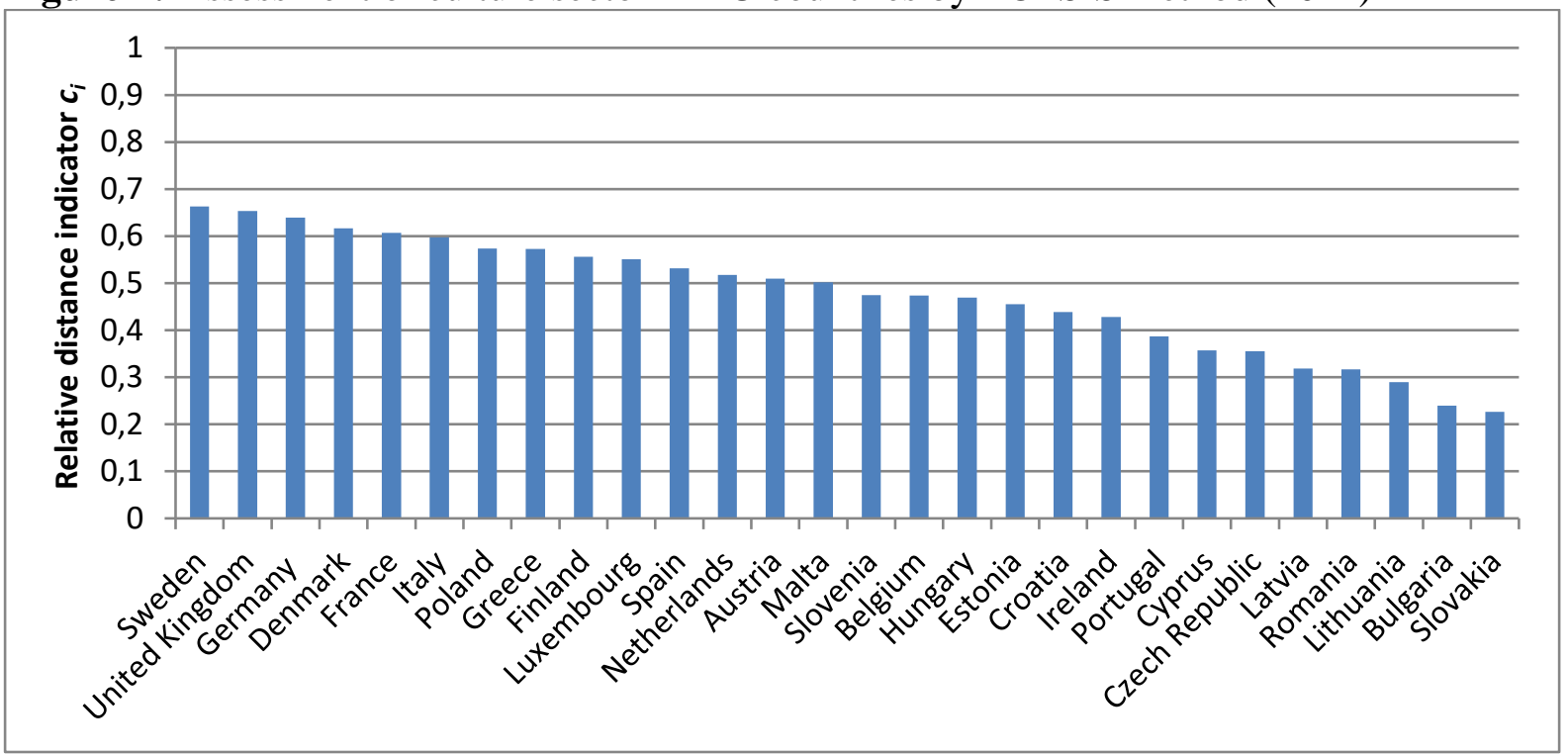

Source: Own research.

The values of the calculated index $c_{i}$ range between 1 and 0 . Value 0 corresponds to the basal alternative; value 1 corresponds to the ideal alternative. The evaluation according to TOPSIS method showed that Sweden ( $1^{\text {st }}$. position), United Kingdom $\left(2^{\text {nd }}\right.$. position) and Germany $\left(3^{\text {rd }}\right.$. position) are on the best places in sense of socio-economic importance of culture sector which highlights the high competitiveness of this sector. The worst rating was found out in case of Lithuania, Bulgaria and Slovakia. The Czech Republic ranked on the $23^{\text {th }}$. position, which makes it one of the EU's below average countries in this field and shows relatively low competitiveness of the sector.

The evaluation of culture sector according to WSA method in EU countries for the year 2014 is represented in Figure 2. The total utility $u\left(a_{i}\right)$ of alternatives was ordered from the highest to the lowest. According to the ranking acquired by the application of WSA method also Sweden (1st. position), United Kingdom (2n. position) and then Germany (3rd. position) ranked on the best places. Lithuania, Bulgaria and Slovakia ranked also on the worst places. The Czech Republic ranked on the $22^{\text {st }}$. position, which shows the under-average level of Czech socioeconomic importance of culture sector among EU countries. 
Figure 2: Assessment of culture sector in EU countries by WSA method (2014)

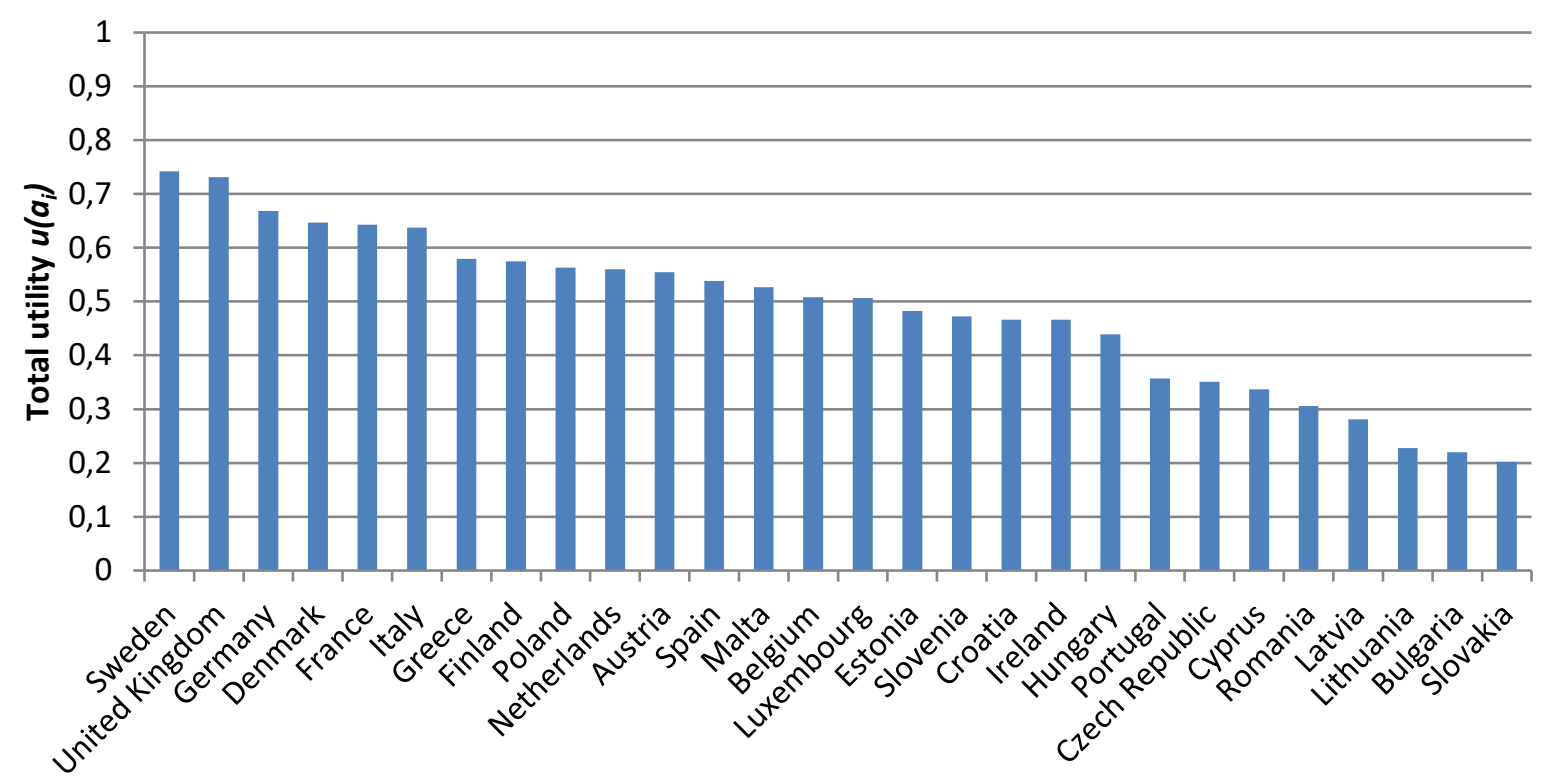

Source: Own research.

Comparison of the socio-economic importance of the culture sector in the EU countries is expressed in Table 2. The ranking of countries is based on the relative distance indicator $c_{i}$ and is expressed as a percentage. The country with the best rating (Sweden) reaches the value of $100 \%$, the country with the worst rating (Slovakia) reaches the value of $34.1 \%$. This points out that the socio-economic importance of culture sector is in Slovakia about $66 \%$ lower than in Sweden. The socio-economic importance of culture sector of the Czech Republic is about $46 \%$ lower than in Sweden. The differences between EU countries are therefore considerable.

Table 2: Socio-economic importance of the EU-countries' ${ }^{`}$ culture sector

\begin{tabular}{|l|l|c|}
\hline $\begin{array}{l}\text { TOPSIS } \\
\text { ranking }\end{array}$ & Country & $\begin{array}{c}\text { Socio-economic } \\
\text { importance in \% }\end{array}$ \\
\hline 1 & Sweden & 100.0 \\
\hline 2 & United Kingdom & 98.5 \\
\hline 3 & Germany & 96.5 \\
\hline 4 & Denmark & 93.0 \\
\hline 5 & France & 91.6 \\
\hline 6 & Italy & 90.1 \\
\hline 7 & Poland & 86.5 \\
\hline 8 & Greece & 86.5 \\
\hline 9 & Finland & 83.9 \\
\hline 10 & Luxembourg & 83.1 \\
\hline 11 & Spain & 80.2 \\
\hline 12 & Netherlands & 78.1 \\
\hline 13 & Austria & 76.9 \\
\hline 14 & Malta & 75.7 \\
\hline
\end{tabular}

\begin{tabular}{|l|l|c|}
\hline $\begin{array}{l}\text { TOPSIS } \\
\text { ranking }\end{array}$ & Country & $\begin{array}{c}\text { Socio-economic } \\
\text { importance in \% }\end{array}$ \\
\hline 15 & Slovenia & 71.6 \\
\hline 16 & Belgium & 71.5 \\
\hline 17 & Hungary & 70.8 \\
\hline 18 & Estonia & 68.7 \\
\hline 19 & Croatia & 66.2 \\
\hline 20 & Ireland & 64.6 \\
\hline 21 & Portugal & 58.3 \\
\hline 22 & Cyprus & 53.8 \\
\hline 23 & Czech Republic & 53.6 \\
\hline 24 & Latvia & 48.0 \\
\hline 25 & Romania & 47.8 \\
\hline 26 & Lithuania & 43.7 \\
\hline 27 & Bulgaria & 36.1 \\
\hline 28 & Slovakia & 34.1 \\
\hline
\end{tabular}

Source: Own research. 
The results of both methods were also verified. By usage of Spearman correlation coefficient the tightness of dependency between the rankings of the EU countries in culture sector was measured, which comes from two MCDM evaluation methods. The auxiliary data are arranged in Table 3.

Table 3: Auxiliary data

\begin{tabular}{|l|l|c|c|c|c|}
\hline Order & Country & $\mathrm{i}_{\mathrm{x}}$ & $\mathrm{i}_{\mathrm{y}}$ & $\mathrm{i}_{\mathrm{x}}-\mathrm{i}_{\mathrm{y}}$ & $\left(\mathrm{i}_{\mathrm{x}}-\mathrm{i}_{\mathrm{y}}\right)^{2}$ \\
\hline 1 & Austria & 13 & 11 & 2 & 4 \\
\hline 2 & Belgium & 16 & 14 & 2 & 4 \\
\hline 3 & Bulgaria & 27 & 27 & 0 & 0 \\
\hline 4 & Croatia & 19 & 18 & 1 & 1 \\
\hline 5 & Cyprus & 22 & 23 & -1 & 1 \\
\hline 6 & Czech Republic & 23 & 22 & 1 & 1 \\
\hline 7 & Denmark & 4 & 4 & 0 & 0 \\
\hline 8 & Estonia & 18 & 16 & 2 & 4 \\
\hline 9 & Finland & 9 & 8 & 1 & 1 \\
\hline 10 & France & 5 & 5 & 0 & 0 \\
\hline 11 & Germany & 3 & 3 & 0 & 0 \\
\hline 12 & Greece & 8 & 7 & 1 & 1 \\
\hline 13 & Hungary & 17 & 20 & -3 & 9 \\
\hline 14 & Ireland & 20 & 19 & 1 & 1 \\
\hline
\end{tabular}

\begin{tabular}{|l|l|c|c|c|c|}
\hline Order & Country & $\mathrm{i}_{\mathrm{x}}$ & $\mathrm{i}_{\mathrm{y}}$ & $\mathrm{i}_{\mathrm{x}}-\mathrm{i}_{\mathrm{y}}$ & $\left(\mathrm{i}_{\mathrm{x}}-\mathrm{i}_{\mathrm{y}}\right)^{2}$ \\
\hline 15 & Italy & 6 & 6 & 0 & 0 \\
\hline 16 & Latvia & 24 & 25 & -1 & 1 \\
\hline 17 & Lithuania & 26 & 26 & 0 & 0 \\
\hline 18 & Luxembourg & 10 & 15 & -5 & 25 \\
\hline 19 & Malta & 14 & 13 & 1 & 1 \\
\hline 20 & Netherlands & 12 & 10 & 2 & 4 \\
\hline 21 & Poland & 7 & 9 & -2 & 4 \\
\hline 22 & Portugal & 21 & 21 & 0 & 0 \\
\hline 23 & Romania & 25 & 24 & 1 & 1 \\
\hline 24 & Slovakia & 28 & 28 & 0 & 0 \\
\hline 25 & Slovenia & 15 & 17 & -2 & 4 \\
\hline 26 & Spain & 11 & 12 & -1 & 1 \\
\hline 27 & Sweden & 1 & 1 & 0 & 0 \\
\hline 28 & United Kingdom & 2 & 2 & 0 & 0 \\
\hline
\end{tabular}

Source: Own research.

The value of the calculated correlation coefficient $r_{s}=0.98139$ indicates that between the rankings of EU countries processed by method TOPSIS and WSA very strong proportional correlation exists. In addition, significance was tested using the test. The value of the test criterion $\left(t=26.06, t_{0,975}(26)=2.056\right)$ falls within the critical field. At the $5 \%$ level of significance, the test hypothesis is rejected. There was demonstrated the statistically significant dependence between rankings of EU countries resulting from the application of TOPSIS and WSA.

\section{Discussion}

The evaluation and measuring of socio-economic benefit play an important role in public policy and also in culture sector. The meaning of this activity is to justify public spending in relevant areas (Mihaiu 2014, Throsby 2004, Turbide and Laurin 2009). The possible option how to evaluate the socio-economic importance of culture sector is to use indicators describing the economy of culture sector (UNESCO 2009 and OECD 2006). In this article the culture sector is evaluated based on the procession of selected socio-economic culture indicators monitored by Eurostat. As the methods used were selected two MCDM methods - TOPSIS and WSA. MCDM methods are nowadays widely used for the evaluations in wide scope of economic areas and their application possibility was confirmed also in case of culture sector evaluation.

The selected methods allowed the comparison of EU countries in terms of socio-economic importance of culture sector. Culture sector importance depends on the values of 7 selected economic and social indicators describing the socio-economic benefit of the country. Culture sector with significant value added, share of employment, well-educated population, innovative and active businesses could be considered a prerequisite for the competitiveness of the sector (ECB 2003). The results showed also significant differences among EU countries (notably the 
EU-15 countries and the so-called Eastern countries that joined the EU later). The developed countries are characterised by high Gross value added in group recreation, culture and religion (COFOG classification) in percentage of total services, significant consumption expenditure of households on culture, relevant employment in culture sector and share of tertiary students in the cultural field and significant business activity in the culture sector. On the other hand the less developed countries are week in these indicators. This suggests that the socio-economic contribution of the culture sector in the lowest-rated country (Slovakia) is based on the relative distance indicator about $66 \%$ lower than in the case of the best-rated country (Sweden). The position of the Czech Republic was evaluated as below average. This is caused by very low Gross value added in group recreation, culture and religion in percentage of total services and very low share of tertiary students in culture-related fields of education on all tertiary students. Also the indicators referring to the Czech business activity in the culture sector are under average.

In the research it was demonstrated that the best results were reached in the EU countries that are considered as leading or the most advanced countries in EU - Sweden, United Kingdom and Germany. This countries are also characterized by high-quality and good functioning public administration based on Performance indicator or Government Effectiveness Indicator of European Central Bank and World Bank (ECB 2003 or World Bank 2016). In this context it could be mentioned that the evaluation of contribution of culture sector in terms of economic development is a current issue discussed in academic field and by researchers. As stated by Chadwicks (2016) culture is an important component of economic development because the arts, heritage and cultural industries create jobs, contribute to long-term economic growth, promote tourism and bring wider societal benefits. Laurent (2014), who processed the comparison of EU countries from the perspective of value-added, stated the United Kingdom, France, Germany and Italy as the four highest contributors to cultural industry value-added in Europe. This confirms the link between economic development and efficiency of culture sector and partly corresponds with the results of the presented research.

The EU countries legging behind in culture sector are Lithuania, Bulgaria and Slovakia. These countries are considered below-average in terms of economic development within the EU. Slovakia was ordered on the last position by both applied methods. It indicated the lowest values in all culture indicators. As stated by Ministry of Culture of Slovakia (MKSR 2014), Slovakia belongs to the EU countries with the highest GDP rates; however, there are significant shortcomings in the supporting of culture in Slovakia. There is lack of targeted support to promote cultural development and missing / insufficiently valid data. This fact could influence the final evaluation outcome in the presented research. Gross value added in group recreation, culture and religion is the lowest among all EU countries also the cultural employment in percentage of total employment is one of the lowest in EU countries. Slovakia showed shortcomings also in the field of business activity, where the numbers of cultural enterprises, their turnover and value added are very low.

In the research, there was also tested the statistically significant dependence between the EU countries' assessments acquired by the application of selected MCDM methods. This statistically significant dependence was demonstrated, it means that between the two sequence variables exists the tight dependence. This has verified the credibility of the output of the EU countries evaluation by MCDM methods. 


\section{Conclusion}

This article was focusing on the socio-economic evaluation of importance of culture sector in developed countries. It introduced the evaluation of $28 \mathrm{EU}$ countries according to 7 selected socio-economic culture indicators by usage of MCDM methods. The results of the evaluation by TOPSIS and WSA method in the year 2014 confirmed that the best ranking in this area belonged to Sweden, United Kingdom and Germany similarly by WSA and TOPSIS method. The worst results were reported in Slovakia, Bulgaria and Lithuania. The lowest values of indicators of cultural enterprises across EU countries were monitored in Slovakia (indicator NCE, CST, VA). The culture sector promotion is one of the aims on the European level. Cultural industries are supported by European Commission to ensure that the cultural sector is able to increasingly contribute to employment and growth across Europe. This involves the provision of direct financial and technical support. Also in the future the Cultural industries should be promoted very intensively and the objectives across EU countries should be harmonized.

The Czech Republic was evaluated by TOPSIS and WSA method similar as country with under average state of culture sector in EU countries. However, the culture sector becomes increasingly important also in the Czech Republic. In order to provide a comprehensive picture of the performance of culture in the Czech Republic, the Cultural Satellite Account was created covering all sectors that fall into the core of Cultural and creative industries. Also the national legislative determination is a prerequisite for good functioning of the overall culture sector. Currently is applied the State Cultural Policy of the CR for years 2015 - 2020 and the Arts Support Concept for the years 2015 - 2020. The current task is to prepare a Strategy for Support of Cultural and Creative Industries following the Arts Support Concept. In this context should be prepared incentives and fostered programs and projects to support the arts market and related business activities. In 2017, an awareness-raising office on Cultural and creative industries should be funded to provide information on how to use programs to support cultural industries. Other programs should be addressed using the Operational Programs.

\section{Acknowledgement}

The paper was created within the financial support of the student grant project SGS No. SP2017/129 "Economic Factors Affecting the Ensuring of Public Services with Collective Consumption" on Faculty of Economics, Technical University of Ostrava.

\section{References}

[1] BADIA, F. and E. BORIN, 2012. Opportunities and Critical Points for the Introduction of Performance Measurement Systems in Theatres - A Comparison between Theoretical Assumptions and Empirical Realities. Journal of Cultural Management and Policy. 2(2), 45-59. ISSN 2224-2554.

[2] CAI, Z. and Y. WANG, 2012. Research Frontiers in Public Sector Performance Measurement. Physics Procedia. 2012, 25, 793-799. ISSN 1875-3892.

[3] CHADWICK, A., 2016. Why culture is important pillar for socioeconomic development in Saudi Arabia. [online]. 2016 [cit. 2017-02-02]. Available: http://www.arabnews.com/node/993991/columns

[4] CHEN, S. J. and C. L. HWANG, 1992. Fuzzy Multiple Attribute Decision Making: Methods and Applications. Berlin: Springer. ISBN 978-3-540-54998-7. 
[5] CHIARAVAlloti, F., 2014. Performance Evaluation in the Arts and Cultural Sector: A Story of Accounting at Its Margins. The Journal of Arts Management, Law, and Society, 44(2), 61-89. ISSN 1063-2921.

[6] COLOMBO, A., 2006. Cultural Economy. The economic impact of the cultural sector from a European perspective. Digithum, 8, 3-9. ISSN 1575-2275.

[7] CRAIK, J., 2005. Dilemmas in Policy Support for the Arts and Cultural Sector. Australian Journal of Public Administration, 64, 6-19. ISSN 1467-8500.

[8] DINCER, S. E., 2011. Multi-Criteria Analysis of Economic Activity for European Union Member States and Candidate Countries: TOPSIS and WSA Applications. European Journal of Social Sciences. 21(4), 563-572. ISSN 1450-2267.

[9] EUROPEAN CENTRAL BANK, 2003. Public sector efficiency: an international comparison. [online]. 2003 [cit. 2017-03-03]. Available: https://www.ecb.europa.eu/pub/pdf/scpwps/ecbwp242.pdf?97d51e6d2cca0da4180e5c215 dcccd8e.

[10] EUROPA, 2017. Supporting Europe's cultural and creative sectors. [online]. 2017 [cit. 2017-03-03]. Available: https://ec.europa.eu/culture/policy_en.

[11] EUROPEAN COMMISSION, 2006. The Economy of Culture in Europe. [online]. 2006 [cit. 2017-02-24]. Available: http://ec.europa.eu/assets/eac/culture/library/studies/cultural-economy_en.pdf.

[12] EUROSTAT, 2016. Culture. [online]. 2016 [cit. 2017-02-15]. Available: http://ec.europa.eu/eurostat/web/culture/overview.

[13] FIALA, P., 2008. Modely a metody rozhodování. Praha: Oeconomica. ISBN978-80-2451981-4.

[14] KAPLAN, R. S., and D. P. NORTON, 2001. Transforming the Balanced Scorecard from Performance Measurement to Strategic Management: Part I. Accounting Horizons. 15(1), 87-104. ISSN 0888-7993.

[15] KARADAYI, M. A. and E. E.KARSAK, 2014. Fuzzy MCDM Approach for Health-Care Performance Assessment in Istanbul. In Proceedings of The 18th World Multi-Conference on Systemics, Cybernetics and Informatics. Orlando, 228-233. ISBN 9781941763049.

[16] KEYVAN-EKBATANI, M. and O. CATS, 2015. Multi-Criteria Appraisal of Multi-Modal Urban Public Transport Systems. Transportation Research Procedia, 10, 1-11. ISSN 2352-1465.

[17] KLAMER, A., L. PETROVA and A. MIGNOSA, 2006. Financing the Arts and Culture in the European Union. [online]. 2006 [cit. 2017-03-24]. Available: http://www.europarl.europa.eu/RegData/etudes/etudes/join/2006/375309/IPOLCULT_ET\%282006\%29375309_EN.pdf.

[18] LAURENT, R., 2014. The cultural industries in France and Europe: Points of Reference and Comparison. Culture chiffres, 7, 1-20, [online]. 2014 [cit. 2017-03-24]. Available:.http://www.cairn-int.info/article-E_CULC_147_0001--the-cultural-industriesin-france-and.htm.

[19] MIHAIU, D., 2014. Measuring Performance In The Public Sector: Between Necessity And Difficulty. Studies in Business and Economics. 9(2), 40-50. ISSN 1842-4120. 
[20] MKSR, 2013. Stratégia rozvoja kreativneho priemyslu v Slovenskej republike. [online]. 2013 [cit. 2017-03-04]. Available: http://www.culture.gov.sk/posobnostministerstva/kreativny-priemysel-165.html.

[21] OECD, 2006. International Measurement of the Economic and Social Importance of Culture. [online]. 2006 [cit. 2017-03-05]. Available: https://www.oecd.org/std/na/37257281.pdf.

[22] SHIH, H., H. SHYUR and E. S. LEE, 2007. An extension of TOPSIS for group decision making. Mathematical and Computer Modelling. 45, 801-813. ISSN 0895-7177.

[23] SHAOUT, A. and M. K. YOUSIF, 2014. Performance Evaluation - Methods and Techniques Survey. International Journal of Computer and Information Technology. 3(5), 966 - 979. ISSN 2078-5828.

[24] THROSBY, D., 2004. Assessing the impacts of a cultural industry. Journal of Arts Management, Law Society, 34(3), 188-204. ISSN 1063-2921.

[25] TURBIDE, J. and C. LAURIN, 2009. Performance Measurement in the Arts Sector: The Case of the Performing Arts. International Journal of Arts Management. 11(2), 56-70. ISSN 1480-8986.

[26] UNESCO, 2009. Measuring the economic contribution of cultural industries. A review and assessment of current methodological approaches. [online]. 2009 [cit. 2017-03-02]. Available: http://uis.unesco.org/sites/default/files/documents/measuring-the-economiccontribution-of-cultural-industries-a-review-and-assessment-of-current-methodologicalapproaches-en_1.pdf.

[27] VAN DER POL, H., 2008. Key role of cultural and creative industries in the economy. In Statistics, Knowledge and Policy, 2007: Measuring and Fostering the Progress of Societies. Paris and Washington, D.C: OECD. 343-353.

[28] VAN DE VALLE, S., 2008. Comparing the performance of national public sectors: conceptual problems. Journal of Productivity and Performance Management. 57(4), 329338. ISSN 1741-0401.

[29] WANG, S. et al., 2016. Using DEA Models to Measure the Performance of Public Culture Services in China. In Computational Science and Computational Intelligence (CSCI), Las Vegas, 1-10, ISBN 9781479930104.

[30] WORLD BANK, 2016. Worldwide Governance Indicators. [online]. 2016 [cit. 2017-0202]. Available: http://info.worldbank.org/governance/wgi/\#home

[31] ZEDKOVÁ, A., 2016. Possibilities of dynamization of cultural tourism products. Acta academica karviniensia, 3, 62-73. ISSN 1212-415X. 